\title{
Partial Sight
}

National Cancer Institute

\section{Source}

National Cancer Institute. Partial Sight. NCI Thesaurus. Code C35127.

Incomplete sight. 